\title{
TEMPORAL VARIATIONS OF FLOW-SEDIMENT RELATIONSHIPS IN A HIGHLY ERODIBLE CATCHMENT OF THE LOESS PLATEAU, CHINA
}

\author{
Guangyao Gao ${ }^{1,3}$, Ying $\mathrm{Ma}^{2 *}$, Bojie $\mathrm{Fu}^{1,3}$ \\ ${ }^{1}$ State Key Laboratory of Urban and Regional Ecology, Research Center for Eco-Environmental Sciences, Chinese Academy of Sciences, Beijing 100085, PR \\ China \\ ${ }^{2}$ Key Laboratory of Water Cycle and Related Land Surface Processes, Institute of Geographic Sciences \& Natural Resources Research, Chinese Academy of \\ Sciences, Beijing 100101, PR China \\ ${ }^{3}$ Joint Center for Global Change Studies, Beijing 100875, PR China
}

Received: 22 July 2015; Revised: 20 September 2015; Accepted: 26 September 2015

\begin{abstract}
The flow-sediment relationship is important to understand the soil erosion and land degradation processes in severe eroded areas. This study researches on variations of streamflow, sediment load, and flow-sediment relationship on multi-temporal scales (annual, flood season and, monthly scales) in a highly erodible catchment of Chinese Loess Plateau. The results demonstrated that the streamflow, sediment load, sediment concentration, runoff coefficient, and sediment coefficient all experienced evident reductions, and the decrease in the middle and downstream stations was more significant compared with the upstream stations. The land use changes and implementation of soil and water conservation measures played major role for the streamflow and sediment load reductions with respect to precipitation change, and the runoff coefficient and sediment coefficient linearly decreased with the percentage of conservation measure area. The runoff-sediment yield relationship on annual, flood season, and monthly scales could be generally characterized by the linear function, and the slopes during the post-change period was lower than those during the pre-change period of sediment load. The sediment concentration-streamflow discharge relationship represented consistent form over the entire study period, and the logarithmic function was appropriate to describe the relationships on the three timescales. The decrease of sediment concentration contributed greatest $(60 \cdot 7 \%)$ to sediment reduction compared with

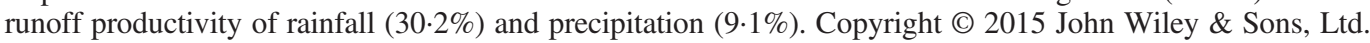

KEY WORDS: $\quad$ soil erosion; flow-sediment relationship; land-use change; multi-temporal scale; loess plateau

\section{INTRODUCTION}

The land degradation processes are triggered by the humankind activities, and they affect the atmosphere, the water resources, the biota, and the soils (Munoz-Rojas et al., 2012; Kröpfl et al., 2013; Parras-Alcántara et al., 2013; Qadir et al., 2013; Berendse et al., 2015). Those impacts use to affect the soil system, which is very complex, and damage the soil services to the societies (Keesstra et al., 2012; Brevik et al., 2015). The hydrological cycle is affected by those changes, and the rivers can act as a source of information to understand the changes in the ecosystems (Keesstra et al., 2007, 2009; Liu et al., 2014; Sanjuán et al., 2014; Borrelli et al., 2015; Zhang et al., 2015). The integrated consequences of climate change and diverse human activities have resulted in distinct temporal-spatial variability of watershed hydrological regimes, especially in water-limited areas (Milly et al., 2005; Cohen et al., 2014). Apparent decreasing and increasing trends in streamflow and sediment load have been reported in many basins around the world (Walling \& Fang, 2003; Milly et al., 2005). Besides streamflow and sediment load, the

*Correspondence to: Y. Ma, Institute of Geographic Sciences \& Natural Resources Research, Chinese Academic of Sciences, Beijing 100101, PR China.

E-mail: maying@igsnrr.ac.cn flow-sediment relationship is also a fundamental element to determine sediment dynamics. The sediment rating curve was proposed to determine the relationship between discharge and suspended sediment load mainly on intraevent or daily timescale (Asselman, 2000; Buendia et al., 2015). The investigation of flow-sediment relationship on multi-temporal scales was useful for the prediction of sediment yield in ungauged basins, especially for severely eroded area such as the Loess Plateau in China.

The Loess Plateau region with a total area of 0.64 million $\mathrm{km}^{2}$ is located in the middle reaches of the Yellow River basin in northern China. The severe soil erosion in the Loess Plateau region was due to highly erodible loessial soil, steep topography, frequent heavy rainfall in summer months, and sparse vegetation stemming from intensive cultivation, and improper land uses (Zhao et al., 2013). To control the severe soil erosion in the Loess Plateau, several soil conservation measures including afforestation, pasture reestablishment, terraces, and check dams have been implemented since the 1950s (Liang et al., 2015). A recent large reforestation campaign, the Grain-for-Green (GFG) project, has been implemented at the end of the 1990s, aim to convert steep croplands to forest and pasture lands (Feng et al., 2012). Meanwhile, the Loess Plateau region has been experiencing a climatic warming and drying trend since the 1950s (Zhao et al., 2013). 
The extensive land-use and land-cover changes caused by the soil and water conservation measures have dramatically altered the hydrological regimes of many watersheds in the Loess Plateau. The change of streamflow and sediment load during the past several decades has received considerable attention. Zhang et al. (2008) indicated that the catchments within the central region of the Loess Plateau had significant decreasing trend in annual streamflow of -0.13 to $-1.58 \mathrm{~mm} \mathrm{y}^{-1}$ since the 1950 s to 2000 . All the 11 catchments in Zhang et al. (2008) experienced significant reduction in annual sediment yield from $-0.03 \times 10^{3}$ to $-0.42 \times 10^{3} \mathrm{Mg} \mathrm{km}^{-2} \mathrm{y}^{-1}$, and annual sediment concentration in seven of the 11 catchments exhibited a statistically significant decreasing trend over time (Rustomji et al., 2008). Zhao et al. (2014) found that nearly all main hydrological stations in the middle reaches of the Yellow River basin recorded significant decreases in annual streamflow with reduction rates ranging from 0.10 to $1.61 \mathrm{mmy}^{-1}$ during 1950s-2010. Abrupt changes in streamflow occurred in the mid-1980s and around 1999 in the tributaries mainly driven by the implementation of soil and water conservation measures, whereas streamflow at mainstream stations showed abrupt changes when large reservoirs were built (Zhao et al., 2014). Furthermore, the components of runoff (surface runoff and baseflow) and streamflow regime in the catchments of the Loess Plateau also exhibited evident changes (Huang et al., 2004; Mu et al., 2007; Gao et al., 2015).

A few studies have been conducted on the relationship between streamflow and sediment load in catchments of Loess Plateau. Rustomji et al. (2008) showed that the sediment rating curves under high-flow samples were similar before and after change point periods of sediment load, and soil conservation practices mainly changed the sediment rating curves under low-flow conditions. Gao et al. (2012) used the linear regressions between the monthly runoff coefficient and sediment coefficient to study the runoffsediment behaviors. Zheng et al. (2012) investigated the flow-sediment relationship over multiple temporal (intraevent, inter-event, and annual) and spatial (plot, subwatershed, and watershed) scales based on recorded data with the periods from ten to 25 years. They found that although the proportional runoff-sediment yield relationship proposed by Zheng et al. (2008) was well applicable from plot to watershed at the event time scale, the relationship between annual runoff volume and annual sediment yield became linear with a non-zero intercept at the watershed scale. However, the study period of Zheng et al. (2012) ended in 1995. There was little information on the variation of flow-sediment relationship during recent decades when the Loess Plateau experienced significant vegetation restoration caused by the GFG project. Furthermore, the flowsediment relationship on flood season and monthly scales was not substantially considered. Most of the runoff and sediment load in the Loess Plateau is generated during months in flood season. Therefore, it is essential to investigate the flow-sediment relationship on annual, flood season, and monthly scales with the long-term recording data.
This study selected a typical hilly-gully and highly erodible watershed (Yanhe watershed) located in the center of the Loess Plateau as the study area. Hydrologic data at five stations distributed in the watershed from 1950s-2012 were collected for detailed analysis. The specific objectives were to (i) detect spatial variation of annual and flood season streamflow and sediment load changes among the stations; (ii) quantify the runoff-sediment yield and sediment concentration-water discharge relationships on annual, flood season, and monthly scales; and (iii) estimate the relative contributions of precipitation, runoff productivity of rainfall, and sediment concentration in runoff to sediment yield reduction with the Kaya identity.

\section{MATERIALS AND METHODS}

\section{Study Area}

The Yanhe River with a length of $284.3 \mathrm{~km}$ is a first-order tributary of the Yellow River in Shaanxi Province, China. The Yanhe watershed $\left(108^{\circ} 38^{\prime}-110^{\circ} 29^{\prime} \mathrm{E}, 36^{\circ} 21^{\prime}-37^{\circ}\right.$ $19^{\prime} \mathrm{N}$ ) is located in the middle of the Loess Plateau (Figure 1), and the area of the whole watershed is $7,725 \mathrm{~km}^{2}$. The watershed has a typical semiarid continental climate. The average annual precipitation (1953-2012) is approximately $500 \mathrm{~mm}$ with an extremely uneven seasonal distribution. About $70 \%$ of precipitation falls from June to September and many short-duration, high-intensity rainstorms concentrated in the rainy season. The annual average temperature and potential evapotranspiration across the watershed is $9.7^{\circ} \mathrm{C}$ and $960 \mathrm{~mm}$, respectively. The watershed is covered by thick loess, which is an erosion-prone silty-loam soil with silt content over 50\% (Fu \& Gulinck, 1994; Wang et al., 2008). Soil loss is severe throughout the basin and causes enormous sedimentation and high flood risks downstream. The mean value of annual average soil loss was $14,458 \mathrm{Mg} \mathrm{km}^{-2}$ per year, and the soil loss rate in most areas was between 5,000 and $20,000 \mathrm{Mg} \mathrm{km}^{-2}$ per year ( $\mathrm{Fu}$ et al., 2005). The landform is a typical loess hilly/gullied landscape

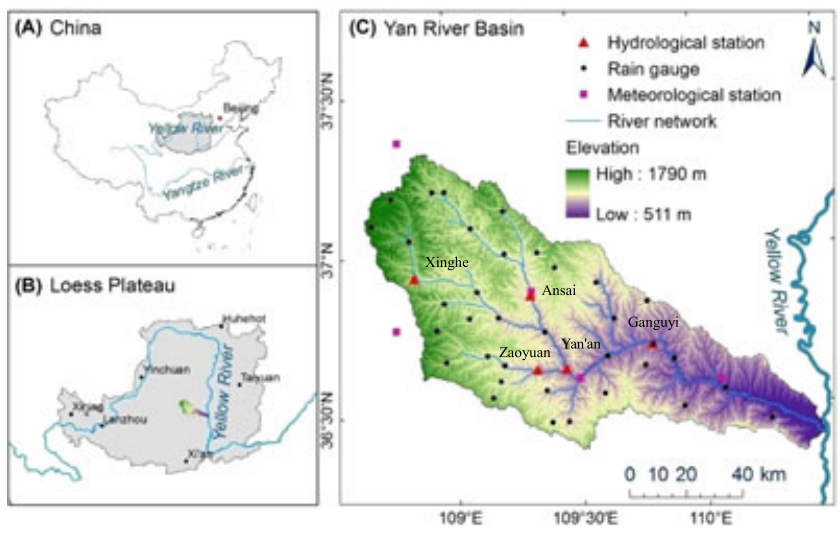

Figure 1. (A) The location of the Loess Plateau (gray shading) in the middle reaches of the Yellow River basin, China, (B) Location of the Yanhe watershed (color shading) in the middle part of the Loess Plateau, (C) An overview of the Yanhe watershed. This figure is available in colour online at wileyonlinelibrary.com/journal/ldr. 
with elevations ranging from 495 to $1795 \mathrm{~m}$ asl, and the gully density ranges from $2 \cdot 1$ to $4.6 \mathrm{~km}^{-2}$ due to long-term soil erosion. The average slope of the region is $23.4^{\circ}$. Forestland, grassland, and cropland are the three dominant land use types accounting for $10.63 \%, 46.05 \%$, and $42.83 \%$ of the watershed area, respectively (Zhao et al., 2012). The natural forests were almost totally destroyed as a result of human disturbances and changes of the natural environmental conditions.

\section{Data Sources}

There were five hydrological stations in the Yanhe watershed (Figure 1). The Ganguyi, Yan'an, and Ansai stations were located in the main stream. The Xinghe and Zaoyuan were the stations in the tributary. The Ansai and Xinghe stations were located in the upper reach. The Yan'an and Zaoyuan stations were located in the middle reach, and Ganguyi station was at the lower reach. The Ganguyi was the final hydrological station in the Yanhe River. The control area and data period of the five stations were shown in Table I. The monthly streamflow, sediment load, and sediment concentration data of the five hydrological stations were obtained from the Bureau of Hydrology, Yellow River Conservancy Commission. Daily precipitation from 1953-2012 at 39 rain gauge stations inside the watershed were also provided by this institute. Daily climate data from 1950 s to 2012 at the five county-level meteorological stations (i.e., Ansai, Yan'an, Yanchang, Zhidan, and Jingbian) in and around the watershed were obtained from the Shaanxi Meteorological Administration, China. The locations of the hydrological, rain gauge stations, and meteorological stations were shown in Figure 1. All the measured data were checked by the corresponding agencies and rated as good quality.

To fully reflect the hydrological characteristics of the watershed, the changes of precipitation $(P, \mathrm{~mm})$, potential evapotranspiration $(P E T, \mathrm{~mm})$, streamflow $\left(R, \mathrm{~m}^{3}\right)$, sediment load $(S, \mathrm{Mg})$, sediment concentration $(S C=S / R$, $\left.\mathrm{kg} \mathrm{m}^{-3}\right)$, runoff coefficient $\left(C_{r}=R /(A . P)\right.$, where $A$ is the control area of hydrological station, $\mathrm{km}^{2}$ ), and sediment coefficient $\left(C_{s}=S /(A . P), \mathrm{Mg} \mathrm{km}^{-2} \mathrm{~mm}^{-1}\right)$ (Liu et al., 2014) were analyzed. The daily potential evapotranspiration was calculated using the FAO Penman-Monteith method with the mean, maximum and minimum air temperatures, vapor pressure, relative humidity, wind speed at two-m height, and bright sunshine hours obtained in the meteorological stations (Allen et al., 1998). The area-average precipitation in the upstream of hydrological station was calculated using the Thiessen Polygon method. The $C_{r}$ and $C_{s}$ signify runoff and sediment availability per unit area per unit precipitation, respectively. In the Loess Plateau, the streamflow and sediment load were mainly produced during the flood season (June-September). Therefore, the changes of previous hydrological variables in both the full year and flood season were examined.

Land use and land cover data at 1980 and 2005 were provided by the Environmental and Ecological Science Data Center for West China (http://westdc.westgis.ac.cn). The classification procedure was based on image interpretation combined with field investigation. Land use and land cover was classified into six categories, namely, forestland, arable land, grassland, residential land, water body, and barren land. Data of the soil and water conservation measures from 1959 to 2006 including the areas of afforestation, grass-planting, level terraces, and check dams were obtained from Liang et al. (2015).

\section{Trend Test}

The significance of the trends in annual meteorological and hydrological time series was estimated by the nonparametric Mann-Kendall (M-K) test (Mann, 1945; Kendall, 1975). A precondition before using the $\mathrm{M}-\mathrm{K}$ test is that the series are independent. In fact, climatic and hydrological series may generally display serial correlation, which can complicate the identification of trends. In this work, the trend-tree pre-whitening method proposed by Yue \& Wang (2002) was used to remove the auto-correlation before executing the trend analysis. A $Z$ statistic was obtained from the $\mathrm{M}-\mathrm{K}$ test on the whitened series with the trend-tree prewhitening method. A negative value of $Z$ indicates a downward trend, and vice versa. The slope of the trend was estimated as follows (Sen, 1968; Hirsch et al.,1982):

$$
\beta=\operatorname{Median}\left[\frac{x_{j}-x_{i}}{j-i}\right] \text { for all } i<j
$$

Where: $\beta$ is the magnitude of the trend, and $x_{i}$ and $x_{j}$ are the sequential data values in periods $i$ and $j$, respectively.

\section{Change-point Analysis}

The non-parametric Pettitt breakpoint test (Pettitt, 1979) has been widely applied to detect the abrupt changes of hydroclimatic variables (Huo et al., 2008; Xu et al., 2013). It is a rank-based and distribution-free test for detecting a significant change in the mean value of a time series. The test uses a version of the Mann-Whitney statistic $U_{t, N}$ that verifies

Table I. The detailed information of hydrological stations in the Yanhe watershed

\begin{tabular}{|c|c|c|c|c|c|c|}
\hline Hydrological station & Location & Longitude (E) & Latitude (N) & Altitude (m) & Area $\left(\mathrm{km}^{2}\right)$ & Data period \\
\hline Ganguyi & Mainstream & $109^{\circ} 48^{\prime}$ & $36^{\circ} 42^{\prime}$ & 900 & 5,891 & 1953-2012 \\
\hline Yan'an & Mainstream & $109^{\circ} 27^{\prime}$ & $36^{\circ} 38^{\prime}$ & 1,000 & 3,208 & 1959-2012 \\
\hline Ansai & Mainstream & $109^{\circ} 19^{\prime}$ & $36^{\circ} 52^{\prime}$ & 1,061 & 1,334 & 1981-2012 \\
\hline Xinghe & Tributary & $108^{\circ} 51^{\prime}$ & $36^{\circ} 56^{\prime}$ & 1,224 & 479 & 1980-2012 \\
\hline Zaoyuan & Tributary & $109^{\circ} 20^{\prime}$ & $36^{\circ} 38^{\prime}$ & 1,029 & 719 & 1971-2012 \\
\hline
\end{tabular}


whether two samples, that is, $x_{1}, \ldots, x_{t}$ and $x_{t+1}, \ldots, x_{N}$, are from the same population. The test statistic $U_{t, N}$ is given by

$$
\begin{aligned}
& U_{t, N}=U_{t-1, N}+\sum_{j=1}^{N} \operatorname{sgn}\left(x_{t}-x_{j}\right) \\
& \text { for } t=2, \ldots \ldots \ldots, N
\end{aligned}
$$

Where: $\operatorname{sgn}(\theta)$ is equal to 1,0 , and -1 if $\theta$ is greater than, equal to, or less than zero, respectively. The breakpoint is defined to be where the absolute value of $U_{t, N}$ reaches its maximum value:

$$
K_{N}=\operatorname{Max}_{1 \leq t \leq N}\left|U_{t, N}\right|
$$

The significance level associated with $K_{N}$ is determined approximately by

$$
p=2 \exp \left\{-6\left(K_{N}\right)^{2} /\left(N^{3}+N^{2}\right)\right\}
$$

\section{Flow-sediment Relationship Analysis}

To investigate the flow-sediment relationship, the annual, flood season and monthly specific sediment yield $\left(S S Y=S / A, \mathrm{Mg} \mathrm{km}^{-2}\right)$, runoff depth $(h=R / A, \mathrm{~mm})$, and streamflow discharge $\left(Q, \mathrm{~m}^{3} \mathrm{~s}^{-1}\right)$ were calculated. As nearly all the sediment load occurred in the flood season, the monthly value only from June to September were used in the study. The $S S Y-h$ and $S C-Q$ relationship on the annual, flood season and monthly timescales were analyzed with the regression method. The proportional, linear, power, and logarithmic functions were used in the regression analysis to detect the best fit flow-sediment relationship in the upstream of each hydrological station.

The changes of sediment load exported from the watershed were driven by precipitation, runoff productivity of rainfall, and sediment concentration in flow. Raupach et al. (2007) applied the Kaya identity to investigate contributions of population, per-capita gross domestic product (GDP), energy intensity of GDP, and carbon intensity of GDP growth rate to global emissions growth. Similarly, the sediment load can be expressed as a product of three driving factors with the Kaya identity:

$$
S=P\left(\frac{h}{P}\right)\left(\frac{S}{h}\right)=P C_{r} S
$$

Where: $s=S / h$ is the sediment load concentrated in unit runoff depth, representing the turbidity degree of flow.

Defining the proportional decrease rate of a quantity $X(t)$ as $r(X)=X^{-1} \mathrm{~d} X / \mathrm{d} t$ with units of $[\text { time }]^{-1}$, the counterpart of the Kaya identity for sediment load proportional decrease rate is as follows:

$$
\begin{aligned}
& \frac{d S / d t}{S}= \frac{d\left(P C_{r} s\right) / d t}{P C_{r} s} \\
&= \frac{C_{r} s(d P / d t)}{P C_{r} s}+\frac{P s\left(d C_{r} / d t\right)}{P C_{r} s}+\frac{P C_{r}(d s / d t)}{P C_{r} s} \\
& \frac{d S / d t}{S}=\frac{d P / d t}{P}+\frac{d C_{r} / d t}{C_{r}}+\frac{d s / d t}{s} \\
& r(S)=r(P)+r\left(C_{r}\right)+r(s)
\end{aligned}
$$

The value of $r(X)$ was calculated by dividing the decrease rate of $X$ to its average value. With the obtained linear relationship of the Kaya identity in Equation (8), the decreasing rate of $S$ was the sum of $P, C_{r}$, and $s$ Kaya factors. The relative contributions of changes in precipitation, runoff productivity of rainfall, and sediment concentration in flow to sediment load reduction could be determined.

\section{RESULTS}

\section{Trends of Precipitation and Potential Evapotranspiration}

The statistics (mean and coefficient of variation) and trend test results of annual $P$ and $P E T$ in the five stations are shown in Table II. The average annual $P$ in the upstream of Xinghe station $(470.2 \mathrm{~mm})$ was lower than that of the

\begin{tabular}{|c|c|c|c|c|c|c|c|c|}
\hline \multirow{2}{*}{$\begin{array}{l}\text { Hydrological } \\
\text { station }\end{array}$} & \multicolumn{4}{|c|}{$P(\mathrm{~mm})$} & \multicolumn{4}{|c|}{$P E T(\mathrm{~mm})$} \\
\hline & Mean & $C_{\mathrm{v}}$ & $\mathrm{Z}$ & $\beta$ & Mean & $C_{\mathrm{v}}$ & Z & $\beta$ \\
\hline Ganguyi & $501 \cdot 66$ & 0.203 & $-1 \cdot 359^{\mathrm{NS}}$ & -0.917 & 962.63 & 0.052 & $1 \cdot 481^{\mathrm{NS}}$ & 0.827 \\
\hline Yan'an & 492.89 & $0 \cdot 218$ & $-1.761^{\mathrm{NS}}$ & $-1 \cdot 270$ & $953 \cdot 16$ & 0.054 & $1 \cdot 238^{\mathrm{NS}}$ & 0.523 \\
\hline Ansai & 502.63 & $0 \cdot 187$ & $-0.535^{\mathrm{NS}}$ & $-1 \cdot 317$ & 998.62 & 0.051 & $1 \cdot 486^{\mathrm{NS}}$ & 0.582 \\
\hline Xinghe & $470 \cdot 20$ & $0 \cdot 203$ & $0.635^{\mathrm{NS}}$ & 1.262 & 963.36 & 0.061 & $1 \cdot 402^{\mathrm{NS}}$ & $0 \cdot 398$ \\
\hline Zaoyuan & $508 \cdot 20$ & 0.202 & $-1.756^{\mathrm{NS}}$ & -2.546 & 918.06 & 0.050 & $1 \cdot 103^{\mathrm{NS}}$ & $0 \cdot 285$ \\
\hline
\end{tabular}
other four stations (about $500 \mathrm{~mm}$ ). The Zaoyuan station had smallest average annual PET in the five stations. The five stations had similar variability in both $P$ and $P E T$ as indicated by their $C_{v}$ values. It could be found that the $P$ in the Ganguyi, Yan'an, Ansai, and Zaoyuan stations showed decreasing trend, whereas increasing trend occurred in the

Table II. Statistics and Mann-Kendall trend analysis results of the annual precipitation $(P)$ and potential evapotranspiration $(P E T)$ in each hydrological station of the Yanhe watershed

${ }^{\mathrm{NS}}$ means not significant at 0.05 level. 
upper reaches of watershed (Xinghe station). The annual $P E T$ showed decreasing trend in the five stations. However, the changes of $P$ and $P E T$ were not significant in the watershed, as evident from the $\mathrm{M}-\mathrm{K}$ test statistic $Z$ values in Table II $(p>0 \cdot 05)$.

\section{Trends of Streamflow and Sediment Load}

The statistics of the annual $R, S, S C, C_{r}, C_{s}, h$, and $S S Y$ of the five hydrological stations are shown in Table III. For the three mainstream stations, the Yan'an station had largest $S C$, and the Ganguyi station had smallest $C_{s}$, whereas, there was little difference of $C_{r}, h$, and $S S Y$ among these three stations (Table III). The average annual $S C, C_{r}, C_{s}, h$, and $S S Y$ at the Zaoyuan station were noticeably lower than those at the other four stations, as shown in Table III. This result indicated that the runoff and sediment production ability in the upstream of the Zaoyuan station were much smaller compared with other areas in the watershed. The $S C, C_{s}$, and $S S Y$ at the Xinghe station were largest in the five stations (Table III), which indicated that the upstream of the Xinghe station had highest sediment production ability in the watershed. Furthermore, the $C_{v}$ values of $S, S C$, and $C_{S}$ were larger than those of $R$ and $C_{r}$ in the five stations, which indicated that the sediment load variables exhibited greater variability than the streamflow variables (Table III).

The M-K trend test results of the annual $R, S, S C, C_{r}$, and $C_{s}$ in the five stations are given in Table IV. Significant decreasing trends were detected for $R, S, S C$, and $C_{S}$ $(p<0.01)$, as well as, $C_{r}(p<0.05)$ at the Ganguyi station. Some decreasing trends occurred at the Yan'an station. Compared with the Ganguyi and Yan'an stations, the decreasing trend of the hydrological variables reduced at the Ansai station. The decreasing trends of $R, S, S C$ and, $C_{S}$ were only at 0.05 significant level, and the $C_{r}$ did not have a significant downward trend at the Ansai station (Table IV). For the two tributary stations, the hydrological variables at the Zaoyuan station had the same significant decreasing trend as those at the Yan'an and Ganguyi stations. As shown in Table IV, the decreasing trend of $R$ was not significant and that of $S$ was only at 0.05 significant level in the Xinghe station, whereas the decreasing trends of $S C, C_{r}$ and $C_{S}$ were extremely significant $(p<0 \cdot 01)$. The aforementioned results indicated that streamflow and sediment showed evident decreasing trend in the watershed, and the significant level was lower in the upper reaches with respect to that in the middle and lower reaches of the watershed. The changing trends of hydrological variables in the flood season were similar to the annual value, but the decreasing trend of streamflow reduced in the flood season. For example, the decreasing trends of $C_{r}$ at the Yan'an station and $R$ at the Ansai station were not significant $(p>0 \cdot 05)$.

\section{Change Points of Streamflow and Sediment Load}

The change-point analysis results of annual streamflow and sediment load at the five hydrological stations are shown in Table V. According to the Pettitt test, the streamflow at

Table III. Statistics of annual streamflow $(R)$, sediment load $(S)$, sediment concentration $(S C)$, runoff coefficient $\left(C_{r}\right)$, sediment coefficient $\left(C_{s}\right)$, runoff depth $(h)$, and specific sediment yield $(S S Y)$ in each hydrological station of the Yanhe watershed

\begin{tabular}{|c|c|c|c|c|c|c|c|c|c|c|c|c|c|c|}
\hline \multirow{2}{*}{$\begin{array}{l}\text { Hydrological } \\
\text { station }\end{array}$} & \multicolumn{2}{|c|}{$R\left(10^{8} \mathrm{~m}^{3}\right)$} & \multicolumn{2}{|c|}{$S\left(10^{4} \mathrm{Mg}\right)$} & \multicolumn{2}{|c|}{$S C\left(\mathrm{~kg} \mathrm{~m}^{-3}\right)$} & \multicolumn{2}{|c|}{$C_{r}(\%)$} & \multicolumn{2}{|c|}{$\begin{array}{c}C_{s}\left(\mathrm{Mg} \mathrm{km}^{-2}\right. \\
\left.\mathrm{mm}^{-1}\right)\end{array}$} & \multicolumn{2}{|c|}{$h(\mathrm{~mm})$} & \multicolumn{2}{|c|}{$\begin{array}{c}S S Y \\
\left(10^{4} \mathrm{Mg} \mathrm{km}^{-2}\right)\end{array}$} \\
\hline & Mean & $C_{\mathrm{v}}$ & Mean & $C_{\mathrm{v}}$ & Mean & $C_{\mathrm{v}}$ & Mean & $C_{\mathrm{v}}$ & Mean & $C_{\mathrm{v}}$ & Mean & $C_{\mathrm{v}}$ & Mean & $C_{\mathrm{v}}$ \\
\hline Ganguyi & $2 \cdot 02$ & $0 \cdot 370$ & $4047 \cdot 31$ & 0.873 & $173 \cdot 47$ & $0 \cdot 556$ & $6 \cdot 78$ & $0 \cdot 258$ & $13 \cdot 20$ & 0.747 & $34 \cdot 20$ & $0 \cdot 370$ & $0 \cdot 69$ & 0.873 \\
\hline Yan'an & $1 \cdot 21$ & $0 \cdot 445$ & 2911.89 & 0.926 & $202 \cdot 41$ & 0.533 & $7 \cdot 46$ & $0 \cdot 339$ & $17 \cdot 33$ & $0 \cdot 780$ & $37 \cdot 01$ & $0 \cdot 435$ & $0 \cdot 89$ & 0.905 \\
\hline Ansai & $0 \cdot 51$ & $0 \cdot 315$ & $1039 \cdot 33$ & 0.945 & $176 \cdot 56$ & 0.660 & $8 \cdot 37$ & $0 \cdot 245$ & $16 \cdot 63$ & 0.851 & $37 \cdot 85$ & $0 \cdot 315$ & 0.78 & 0.945 \\
\hline Xinghe & $0 \cdot 17$ & $0 \cdot 332$ & $430 \cdot 73$ & 0.721 & $227 \cdot 26$ & $0 \cdot 461$ & $7 \cdot 55$ & $0 \cdot 265$ & $18 \cdot 73$ & 0.657 & $35 \cdot 32$ & $0 \cdot 332$ & $0 \cdot 90$ & 0.721 \\
\hline Zaoyuan & $0 \cdot 22$ & $0 \cdot 411$ & $301 \cdot 22$ & 0.929 & 121.90 & 0.567 & $5 \cdot 78$ & $0 \cdot 312$ & $8 \cdot 05$ & $0 \cdot 820$ & $29 \cdot 46$ & $0 \cdot 411$ & $0 \cdot 42$ & 0.929 \\
\hline
\end{tabular}

Table IV. Mann-Kendall trend analysis results of annual streamflow $(R)$, sediment load $(S)$, sediment concentration $(S C)$, runoff coefficient $\left(C_{r}\right)$, and sediment coefficient $\left(C_{s}\right)$ in each hydrological station of the Yanhe watershed

\begin{tabular}{|c|c|c|c|c|c|c|c|c|c|c|}
\hline \multirow{2}{*}{$\begin{array}{l}\text { Hydrological } \\
\text { station }\end{array}$} & \multicolumn{2}{|c|}{$R\left(10^{8} \mathrm{~m}^{3}\right)$} & \multicolumn{2}{|c|}{$S\left(10^{4} \mathrm{Mg}\right)$} & \multicolumn{2}{|c|}{$S C\left(\mathrm{~kg} \mathrm{~m}^{-3}\right)$} & \multicolumn{2}{|c|}{$C_{r}(\%)$} & \multicolumn{2}{|c|}{$C_{s}\left(\mathrm{Mg} \mathrm{km}^{-2} \mathrm{~mm}^{-1}\right)$} \\
\hline & $\mathrm{Z}$ & $\beta$ & $\mathrm{Z}$ & $\beta$ & $\mathrm{Z}$ & $\beta$ & Z & $\beta$ & Z & $\beta$ \\
\hline Ganguyi & $-3 \cdot 304 * *$ & $-0 \cdot 017$ & $-3 \cdot 922 * *$ & $-70 \cdot 368$ & $-4 \cdot 101 * *$ & $-3 \cdot 123$ & $-2 \cdot 468^{*}$ & -0.034 & $-3.693 * *$ & -0.235 \\
\hline Yan'an & $-3 \cdot 238 * *$ & $-0 \cdot 013$ & $-3 \cdot 133 * *$ & -45.738 & $-3 \cdot 104 * *$ & $-3 \cdot 286$ & $-2.253^{*}$ & $-0 \cdot 056$ & $-2.775^{* *}$ & $-0 \cdot 271$ \\
\hline Ansai & $-2 \cdot 157 *$ & -0.004 & $-2 \cdot 124 *$ & $-27 \cdot 300$ & $-2 \cdot 124^{*}$ & -4.686 & $-0.892^{\mathrm{NS}}$ & -0.037 & $-1.962^{*}$ & -0.397 \\
\hline Xinghe & $-1 \cdot 720^{\mathrm{NS}}$ & -0.001 & $-2 \cdot 464 *$ & $-12 \cdot 670$ & $-2 \cdot 805^{* *}$ & $-5 \cdot 738$ & $-2.588^{* *}$ & $-0 \cdot 090$ & $-2.928 * *$ & -0.589 \\
\hline Zaoyuan & $-3 \cdot 370 * *$ & -0.003 & $-2.904 * *$ & $-7 \cdot 048$ & $-2 \cdot 861 * *$ & -2.559 & $-2 \cdot 168^{*}$ & $-0 \cdot 050$ & $-2 \cdot 818 * *$ & $-0 \cdot 184$ \\
\hline
\end{tabular}

$\mathrm{NS}_{\text {means not significant at } 0 \cdot 05 \text { level. }}$

*indicate significance levels of $p=0 \cdot 05$

$* *$ indicate significance levels of $p=0 \cdot 01$. 
Table V. Pettitt change-point analysis results of annual streamflow $(R)$ and sediment load $(S)$ in each hydrological station of the Yanhe watershed

\begin{tabular}{|c|c|c|c|c|c|c|c|c|c|c|}
\hline \multirow[b]{2}{*}{$\begin{array}{l}\text { Hydrological } \\
\text { station }\end{array}$} & \multicolumn{5}{|c|}{$R$} & \multicolumn{5}{|c|}{$S$} \\
\hline & Year & $p$ & $\begin{array}{c}\text { Pre-T } \\
\left(10^{8} \mathrm{~m}^{3}\right)\end{array}$ & $\begin{array}{l}\text { Post-T } \\
\left(10^{8} \mathrm{~m}^{3}\right)\end{array}$ & $\begin{array}{c}\text { Change } \\
(\%)\end{array}$ & Year & $p$ & $\begin{array}{c}\text { Pre-T } \\
\left(10^{4} \mathrm{Mg}\right)\end{array}$ & $\begin{array}{l}\text { Post-T } \\
\left(10^{4} \mathrm{Mg}\right)\end{array}$ & $\begin{array}{c}\text { Change } \\
(\%)\end{array}$ \\
\hline Ganguyi & 1996 & 0.001 & $2 \cdot 23$ & 1.43 & $-36 \cdot 02$ & 1996 & 0.001 & $4986 \cdot 72$ & 1463.95 & $-70 \cdot 64$ \\
\hline Yan'an & 1996 & $0 \cdot 0004$ & 1.39 & $0 \cdot 78$ & $-43 \cdot 02$ & 1996 & 0.004 & $3653 \cdot 17$ & $1151 \cdot 35$ & $-68.48 \%$ \\
\hline Ansai & 1996 & $0 \cdot 013$ & $0 \cdot 57$ & $0 \cdot 44$ & $-22 \cdot 50$ & 2002 & 0.008 & 1378.08 & $294 \cdot 08$ & -78.66 \\
\hline Xinghe & 1996 & $0 \cdot 070$ & $0 \cdot 19$ & $0 \cdot 14$ & $-22 \cdot 52$ & 2002 & 0.021 & $534 \cdot 79$ & $191 \cdot 38$ & $-64 \cdot 21$ \\
\hline Zaoyuan & 1996 & $0 \cdot 001$ & $0 \cdot 25$ & $0 \cdot 15$ & -38.94 & 1996 & 0.002 & $408 \cdot 81$ & $126 \cdot 41$ & -69.08 \\
\hline
\end{tabular}

the five stations had the same change point year (1996). The occurrence of this change point is reasonable as it is consistent with the beginning time of the large afforestation campaign (GFG project). The abrupt change points were statistically significant $(p<0.05)$ except that at the Xinghe station. The streamflow after the change point decreased by about $22 \%$ at the Ansai and Xinghe stations, which was smaller than the reduction at the other three stations (39\%). As shown in Table V, the change points of sediment load in the upper reach stations (2002) lagged behind those in the middle and lower reach stations (1996). All the change points of sediment load were at significant level $(p<0 \cdot 05)$. The sediment load after the change point reduced by about $70 \%$ at the five stations, which exhibited greater reductions compared with streamflow. The change points of flood season streamflow and sediment load at each station were the same to those of annual value.

\section{Flow-sediment Relationships}

The annual and flood season $S S Y-h$ relationships $\left(S S Y_{a}-h_{a}\right.$ and $S S Y_{f}-h_{f}$ ) for the pre and post change point period at the five stations are shown in Figure 2. All the $S S Y_{a}-h_{a}$ and $S S Y_{f}-h_{f}$ relationships could be well fitted with the linear function as indicated by the $R^{2}$ values with the only exception of $S S Y_{a}-h_{a}$ during the post-change period at the Ansai station. It could be found that the $S S Y_{f}-h_{f}$ regression lines lied above those of $S S Y_{a}-h_{a}$. This was attributed to the sediment productive ability of runoff during the flood season that was much greater than that over the full year due to the significant contributions of flood events. Furthermore, the slopes of $S S Y_{a}-h_{a}$ and $S S Y_{f}-h_{f}$ regression lines during the post-change period were lower than those during the pre-change period. This was expected as the implementing soil and water conservation measures the trapped sediment and evidently reduced the sediment productivity capacity of flow during the post-change period. Similar to the $S S Y_{a}-h_{a}$ and $S S Y_{f}-h_{f}$ relationships, the $S S Y-h$ relationship on monthly scale $\left(S S Y_{m}-h_{m}\right)$ could be also well described by the linear function, and the slopes of $S S Y_{m}-h_{m}$ regression line during the post-change period greatly decreased as evident from Figure 3. The aforementioned results substantially indicated that the runoff-sediment yield relationship on annual, flood season, and monthly scales could be generally characterized by the linear function in the watershed.

For the $S C-Q$ relationship, the usually used power sediment rating curve $\left(S C=a Q^{b}\right)$ exhibited significant scatter and it distinctly over-predicted sediment concentration at large values of discharge (taking the Ganguyi station as an example, Figure 4). In contrast, the logarithmic function $(S C=a \ln (Q)+b)$ was appropriate to describe both the annual and flood season $S C-Q$ relationships $\left(S C_{a}-Q_{a}\right.$ and $S C_{f}-Q_{f}$ ), as evident from Figure 5. It could be found that the distribution of $S C_{f}-Q_{f}$ exhibited greater span than that of $S C_{a}-Q_{a}$. This was due to the flood season sediment concentration, and streamflow discharge had larger variations over the study period compared with the annual values. The $S C-Q$ relationship on monthly scale $\left(S C_{m}-Q_{m}\right)$ could be also fitted by the logarithmic function (Figure 6). As the scatter plots of $S C_{m}$ versus $Q_{m}$ demonstrated evident variations, the fitting deviations of logarithmic function for $S C_{m}-Q_{m}$ were greater than those for $S C_{a}-Q_{a}$ and $S C_{f}-Q_{f}$ with comparison of Figures 5 and 6. It was interesting to note that the $S C-Q$ relationships on annual, flood season, and monthly scales represented consistent behavior over the entire study period (Figures 5 and 6), which was different from the $S S Y-h$ relationship demonstrating distinct different behaviors before and after the change point of sediment load (Figures 2 and 3). This result indicated that the soil and water conservation measures did not resulted in significant changes of sediment concentration-streamflow discharge relationship in the watershed.

Figure 7 shows the relative contributions of precipitation, runoff productivity of rainfall, and sediment concentration in flow changes to annual and flood season sediment load reduction after the change point with the Kaya identity in Equation (8). It could be found that all these three variables had positive effects on the sediment load reductions at the five stations except the precipitation at the Xinghe station as it represented increasing trend. The relative contributions of these variables to annual sediment load reduction were in the order of sediment concentration in flow $(65.0 \%)$, runoff productivity of rainfall $(25.3 \%)$, and precipitation $(9.7 \%)$. The soil and water conservation measures the reduced sediment export mainly through trapping the sediment and decreasing the sediment concentration. For the flood season sediment 

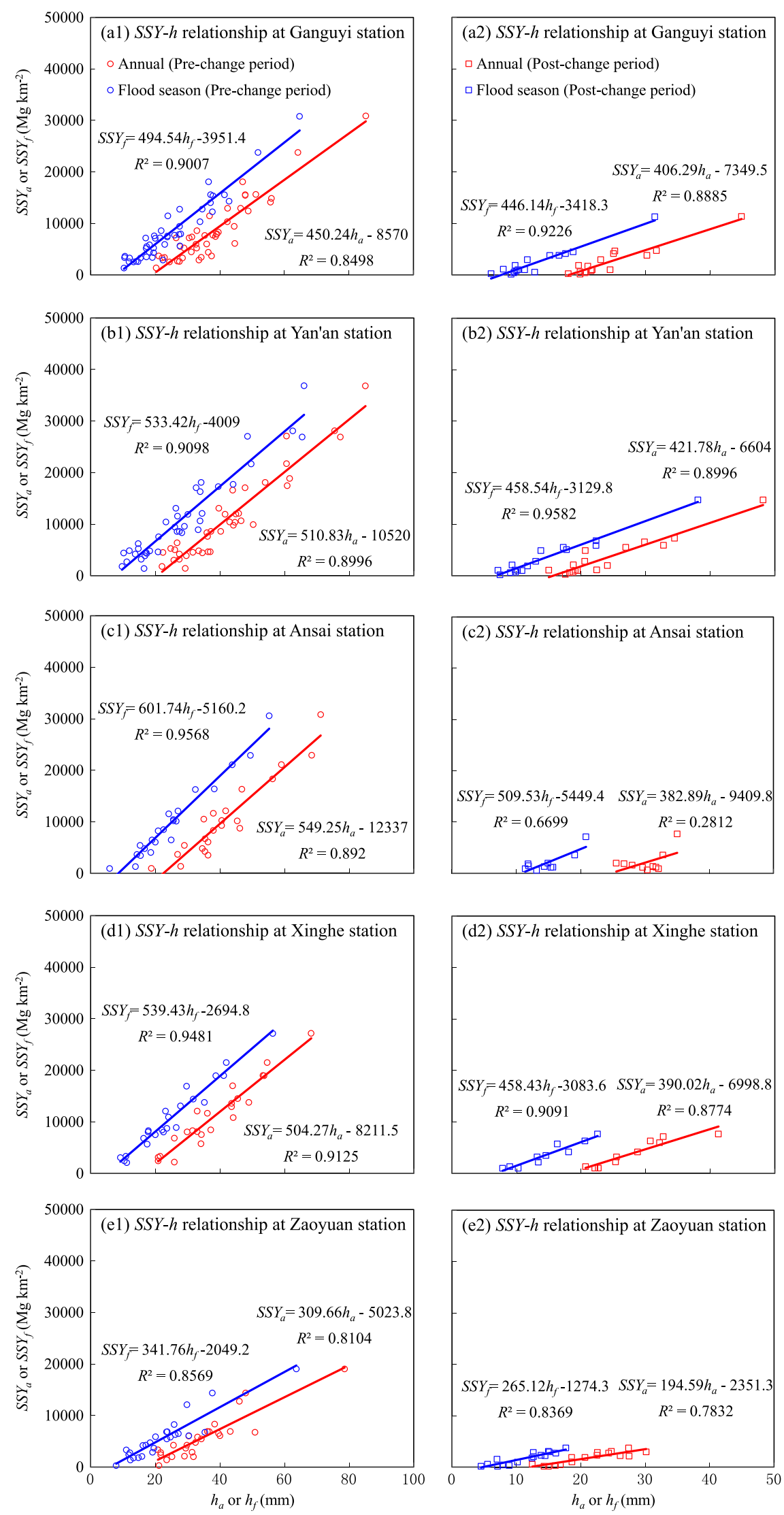

Figure 2. The annual and flood season $S S Y-h$ relationships $\left(S S Y_{a}-h_{a}\right.$ and $\left.S S Y_{f}-h_{f}\right)$ during the (A) pre-change and (B) post-change period of sediment load at the five hydrological stations. $S S Y_{a}$ and $S S Y_{f}$ is annual and flood season specific sediment yield, respectively. $h_{a}$ and $h_{f}$ is annual and flood season runoff depth, respectively. This figure is available in colour online at wileyonlinelibrary.com/journal/ldr. 

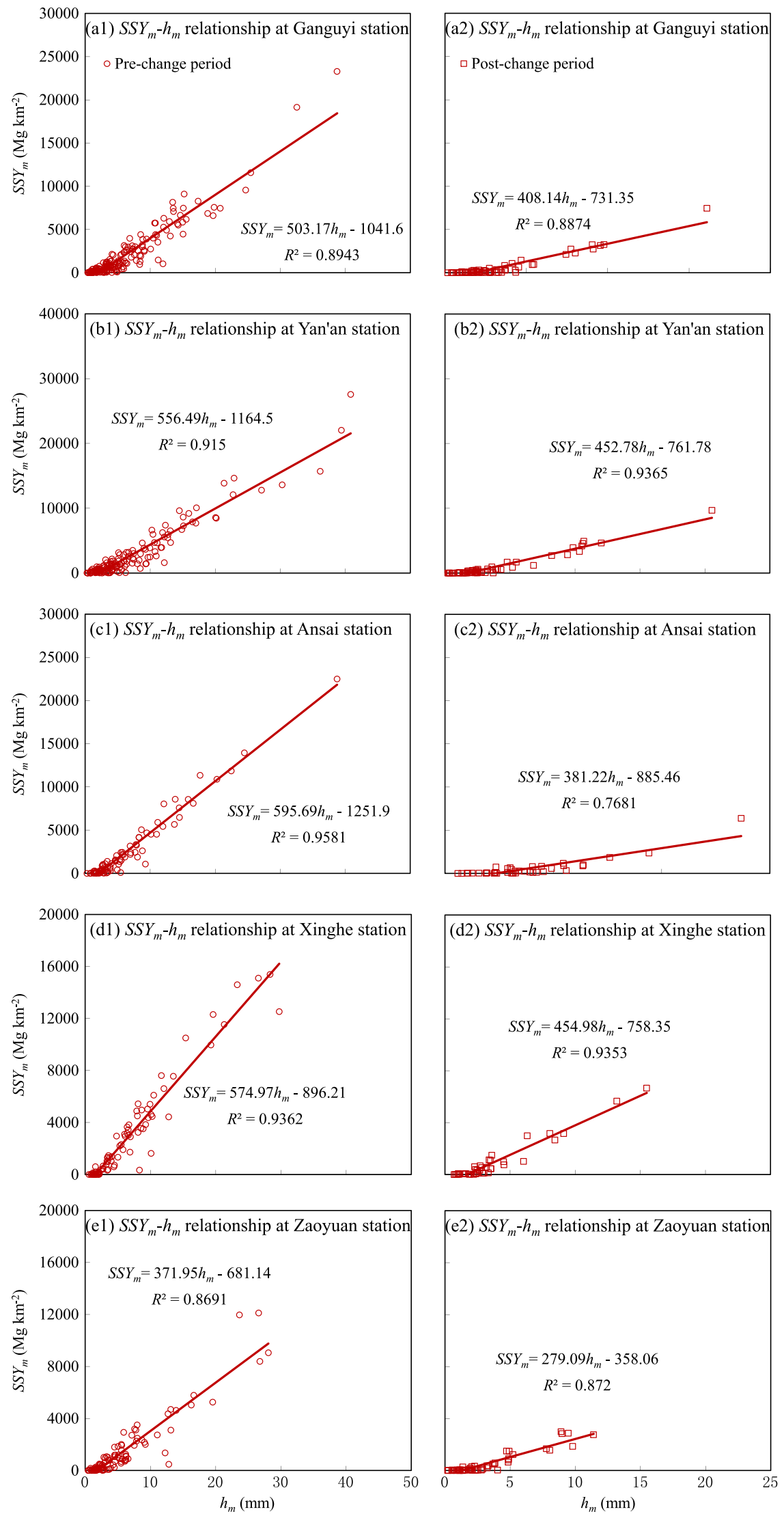

Figure 3. The monthly $S S Y-h$ relationships $\left(S S Y_{m}-h_{m}\right)$ during the (A) pre-change and (B) post-change period of sediment load at the five hydrological stations. $S S Y_{m}$ is monthly specific sediment yield and $h_{m}$ is monthly runoff depth. This figure is available in colour online at wileyonlinelibrary.com/journal/ldr. 

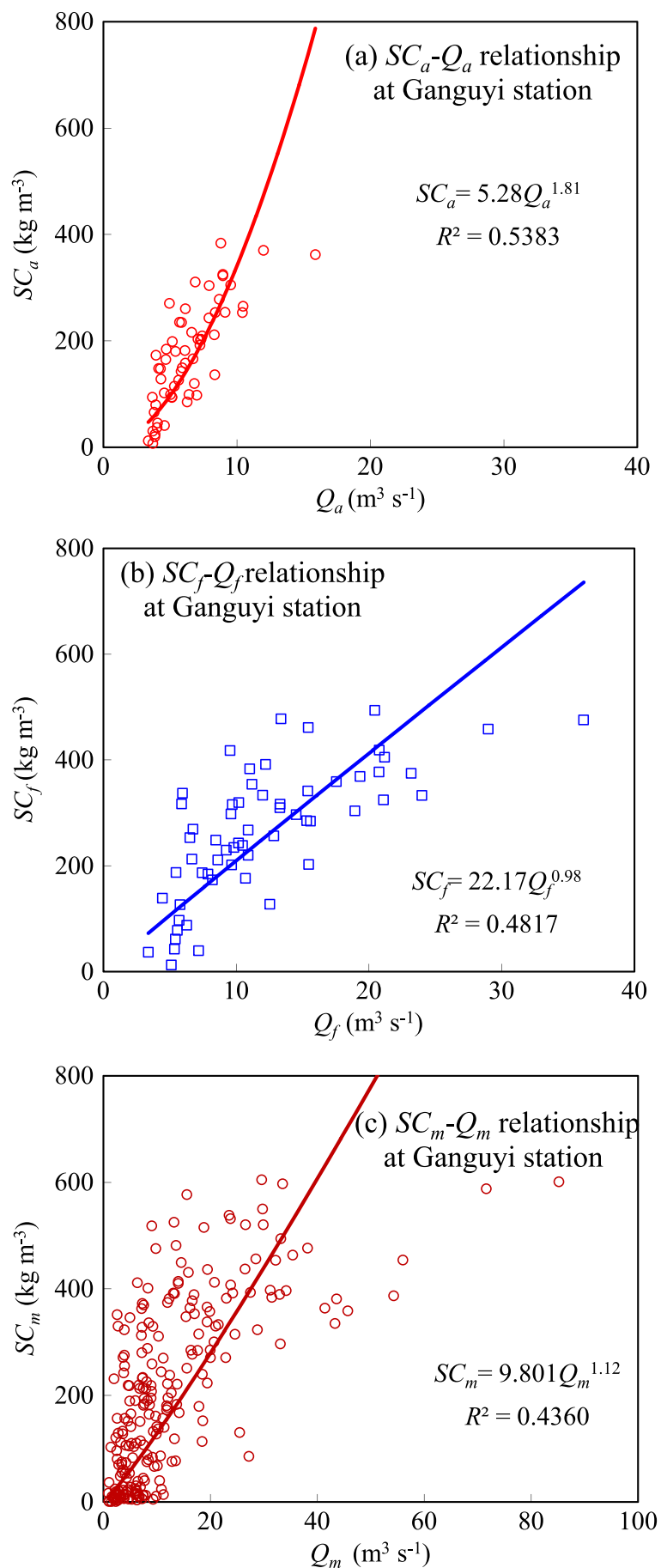

Figure 4. Regression results of the (A) annual, (B) flood season, and (C) monthly $S C-Q$ relationships with the power function at the Ganguyi station. $S C_{a}, S C_{f}$, and $S C_{m}$ is annual, flood season, and monthly sediment concentration, respectively. $Q_{a}, Q_{f}$, and $Q_{m}$ is annual, flood season, and monthly streamflow discharge, respectively. This figure is available in colour online at wileyonlinelibrary.com/journal/ldr.

load reduction, the contribution of precipitation $(8.6 \%)$ had little change, whereas that of runoff productivity of rainfall $(35.0 \%)$ increased and sediment concentration in flow $(56.4 \%)$ decreased evidently. The earlier results indicated that the reduced sediment yield appeared to be largely a product of the reduction in sediment mobility within the watershed.
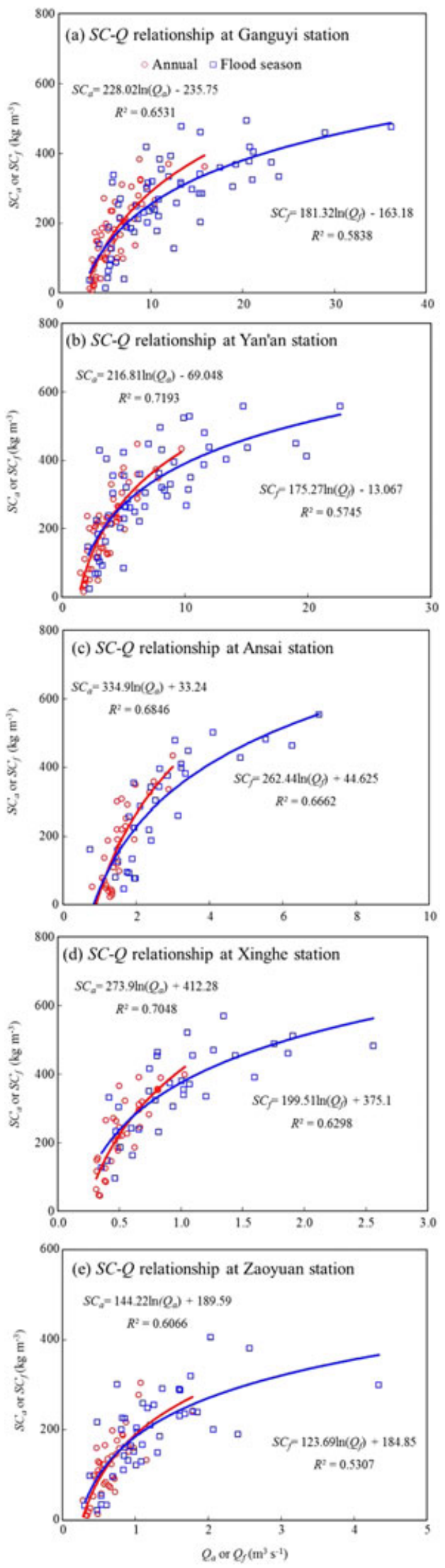

Figure 5. The annual and flood season $S C-Q$ relationships $\left(S C_{a}-Q_{a}\right.$ and $S C_{f}-Q_{f}$ ) at the five hydrological stations. $S C_{a}$ and $S C_{f}$ is annual and flood season sediment concentration, respectively. $Q_{a}$ and $Q_{f}$ is annual and flood season streamflow discharge, respectively. This figure is available in colour online at wileyonlinelibrary.com/journal//dr. 

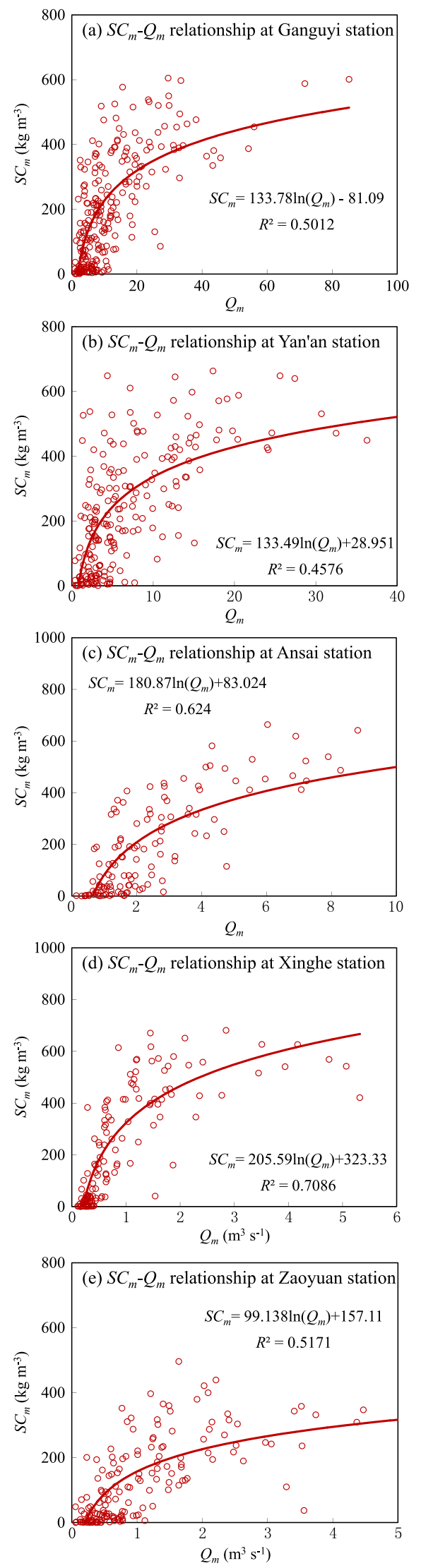

Figure 6. The monthly $S C-Q$ relationship $\left(S C_{m}-Q_{m}\right)$ at the five hydrological stations. $S C_{m}$ is monthly sediment concentration and $Q_{m}$ is monthly streamflow discharge. This figure is available in colour online at wileyonlinelibrary.com/journal/ldr.
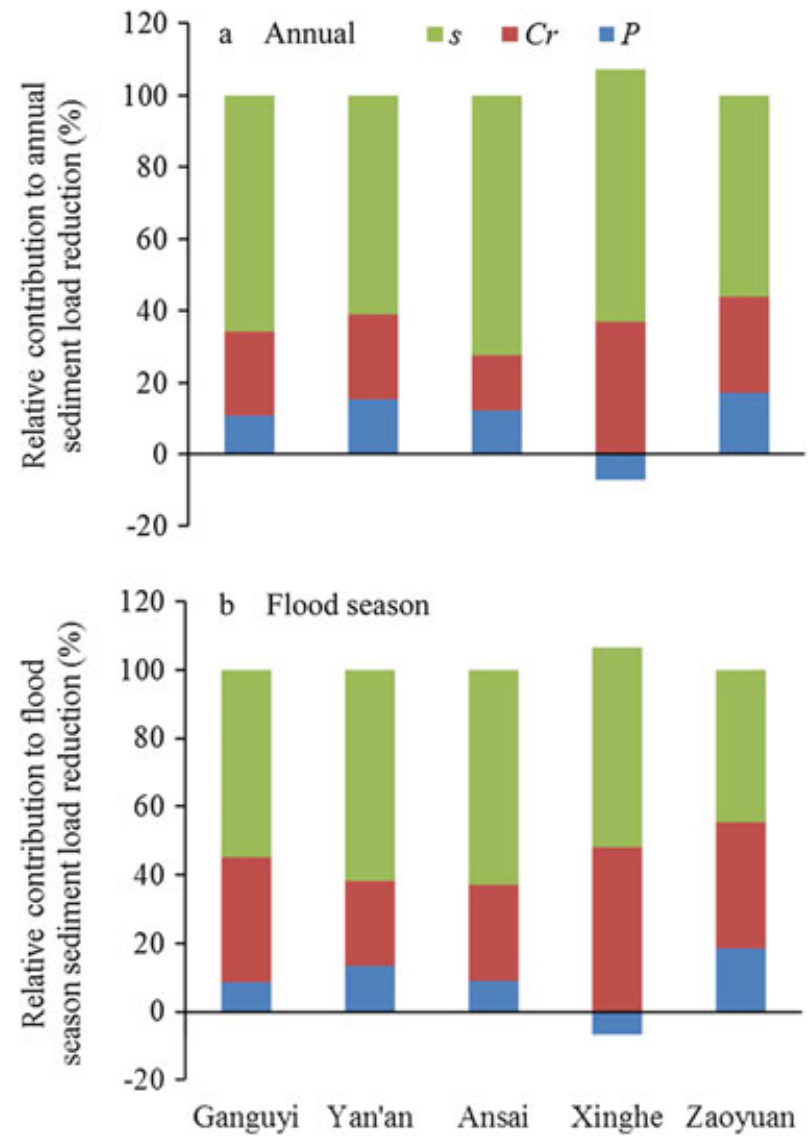

Figure 7. The relative contributions of precipitation $(P)$, runoff productivity of rainfall $(\mathrm{Cr})$, and sediment concentration in flow $(s)$ to the (A) annual and (B) flood season sediment load reductions after the change point with the Kaya identity. This figure is available in colour online at wileyonlinelibrary.com/ journal/ldr.

\section{DISCUSSION}

This study indicated that the watershed experiencedevident reductions of streamflow and sediment load. The precipitation and potential evapotranspiration showed no significant change, whereas the runoff coefficient and sediment coefficient indicated significant decrease. This result was also found in other regions of the world at different scales (from pedon to slope and watershed scale), which was a consequence of the reduction in the soil erosion mainly due to the vegetation cover and soil and water conservation measures that affect the detachment, but also the transport of sediment in the river channels (Cerdà, 1998; Cerdà \& Doerr, 2005; Keesstra et al., 2012, 2014; Gabarrón-Galeote et al., 2013; Bisantino et al., 2015; Serrano-Muela et al., 2015). Furthermore, the regression analysis indicated that the correlations of the precipitation-streamflow and precipitationsediment load relationships before the change point were much stronger than those after the change point in the five stations, and the slope of the regression line during the post-change period was greatly smaller than that before the change point. The streamflow and sediment load production ability of precipitation decreased 
substantially. We used the linear regression equation between annual streamflow and sediment load with precipitation in the pre-change period to estimate the relative influence of precipitation and human activities. The results indicated that human activities contributed more than precipitation to the reductions in streamflow $(63.56 \%$ vs $26.44 \%)$ and sediment load $(71.12 \%$ vs $18.88 \%)$. The aforementioned analysis supported that the streamflow and sediment load reductions were primarily driven by the land use changes and implementation of soil and water conservation measures.

Table VI shows the transfer between different kinds of land use categories in 1980 and 2005. Forestland, arable land, and grassland accounted for more than $99.40 \%$ of the whole area. During this period, there was a net increase of $182.78 \mathrm{~km}^{2}$ in forestland area, accounting for $41.22 \%$ of the total area of forestland in 1980 . In contrast, the area of arable land area decreased $160.92 \mathrm{~km}^{2}$ (about $5.99 \%$ of the total area for arable land in 1980). The area of grassland had no evident change from 1980 $\left(2737.70 \mathrm{~km}^{2}\right)$ to $2005\left(2712.70 \mathrm{~km}^{2}\right)$. The conversion of arable land to forestland and grassland $\left(142.18 \mathrm{~km}^{2}\right.$ and $26.72 \mathrm{~km}^{2}$, respectively) was supported by the GFG project. More vegetation cover the reduced transformation of rainfall into runoff and increased rainfall infiltration and evapotranspiration. The literature review study of McVicar et al. (2007) indicated that the annual streamflow was reduced by between $10 \%$ and $70 \%$ due to afforestation in the Loess Plateau region. The GFG or reforestation project resulted in the significant increase of vegetation cover and undoubtedly contributed largely to reductions in runoff and sediment production (Begueria et al., 2003; Rustomji et al., 2008; Keesstra et al., 2009; Miao et al., 2012).

Besides the land use change, the spatial patterns of land cover within the watershed determine, at least partially, the characteristics of hydrological connectivity processes, the temporal storage of runoff and run-on, and sediment delivery (Bakker et al., 2008; Van Nieuwenhuyse et al., 2011; Marchamalo et al., 2015). It is conceivable that land cover patterns affect the runoff processes that carry eroded soils into streams and rivers, while the proportions of certain land cover types determine the erosion rates within watershed (Borselli et al., 2008; Shi et al., 2013). In the Yanhe watershed, all categories of land were distributed as small fragmentized pieces due to the great dissected landform. Major land use/cover changes from 1980 to 2005 occurred in the upper reaches. Furthermore, the patches of forestland and grassland in the upstream area expanded and even joined together. The aforementioned spatial variation of land cover resulted in the lower significant level of decreasing trend and latter change point of streamflow and sediment load in the upstream area with respect to the midstream and downstream.

The soil and water conservation measures in the Loess Plateau include both biological (e.g., afforestation and planting grass) and engineering (e.g., creation of level terraces, building check dams and gully control projects) measures (Liang et al., 2015). The area of soil and water conservation measures in the Yanhe watershed increased evidently from 1959 to 2006 (Table VII). The percentage of the total treated area increased from $0.85 \%$ in 1959 to $45.78 \%$ in 2006 . The rate of increase was greater during the 1980s due to comprehensive management of small watersheds and after 1996 as a result of the implementation of the GFG project. Although the engineering measures were utilized over much smaller areas than the biological measures (Table VII), these techniques were expected to have immediate and substantial trapping effects on streamflow and sediment load reductions (Mekonnen et al., 2014, 2015). It was reported that the creation of level terraces decreased the average runoff and sediment load by $86.70 \%$ and $95.00 \%$ in the Loess Plateau, respectively (Miao et al., 2010). Building check dams has been the most effective measure to retain sediment (Boix Fayos et al., 2007; Zhao et al., 2013). Xu et al. (2013) estimated that the runoff and sediment in the rainy reason were reduced by up to $28.9 \%$ and $85.5 \%$ due to check dams in the Yanhe watershed, respectively. However, the effects of check dams in reducing the sediment yield at catchment outlet represented scale-dependency, and optimizing the distribution and number of check dams with combination of land use planning is more sustainable management strategy for long-term sediment control (Quiñonero-Rubio et al., 2014; Mekonnen et al., 2015).

For the quantitative effects of soil and water conservation measures on streamflow and sediment load reductions, we found that the runoff coefficient and sediment coefficient at the Ganguyi station linearly decreased with

Table VI. The land use transition matrix from 1980 to 2005 in the Yanhe watershed $\left(\mathrm{km}^{2}\right)$

\begin{tabular}{|c|c|c|c|c|c|c|c|}
\hline 1980-2005 & Forestland & Arable land & Grassland & Residential land & Water body & Barren land & Total in 1980 \\
\hline Forest land & $443 \cdot 34$ & - & $0 \cdot 01$ & $0 \cdot 06$ & - & - & $443 \cdot 41$ \\
\hline Arable land & $142 \cdot 18$ & 2509.93 & $26 \cdot 72$ & $4 \cdot 87$ & 0.33 & - & 2684.02 \\
\hline Grassland & $40 \cdot 67$ & $7 \cdot 92$ & 2685.97 & $3 \cdot 14$ & $0 \cdot 00$ & - & $2737 \cdot 70$ \\
\hline Residential land & - & - & - & $8 \cdot 25$ & - & - & $8 \cdot 25$ \\
\hline Water body & - & $5 \cdot 26$ & - & $0 \cdot 20$ & $10 \cdot 76$ & - & $16 \cdot 21$ \\
\hline Barren land & - & - & - & - & - & $2 \cdot 16$ & $2 \cdot 16$ \\
\hline Total in 2005 & $626 \cdot 19$ & $2523 \cdot 10$ & $2712 \cdot 70$ & $16 \cdot 52$ & $11 \cdot 08$ & $2 \cdot 16$ & 5891.74 \\
\hline
\end{tabular}


Table VII. Cumulative area of major soil and water conservation measures in the Yanhe watershed from 1950 s to $2006^{\mathrm{a}}$

\begin{tabular}{|c|c|c|c|c|c|c|}
\hline Year & $\begin{array}{l}\text { Terraces } \\
\left(\mathrm{km}^{2}\right)\end{array}$ & $\begin{array}{l}\text { Afforestation } \\
\left(\mathrm{km}^{2}\right)\end{array}$ & $\begin{array}{c}\text { Garss-planting } \\
\left(\mathrm{km}^{2}\right)\end{array}$ & $\begin{array}{l}\text { Land created by } \\
\text { check dams }\left(\mathrm{km}^{2}\right)\end{array}$ & $\begin{array}{l}\text { Total area } \\
\quad\left(\mathrm{km}^{2}\right)\end{array}$ & $\begin{array}{l}\text { Percentage of } \\
\text { area affected }\end{array}$ \\
\hline 1959 & 4 & 41 & 0 & 5 & 50 & 0.85 \\
\hline 1969 & 47 & 161 & 4 & 16 & 228 & 3.87 \\
\hline 1979 & 98 & 287 & 18 & 29 & 432 & $7 \cdot 33$ \\
\hline 1989 & 174 & 841 & 145 & 38 & 1198 & $20 \cdot 34$ \\
\hline 1999 & 185 & 1314 & 114 & 24 & 1637 & $27 \cdot 79$ \\
\hline
\end{tabular}

${ }^{\mathrm{a}}$ From Liang et al. (2015).

the percentage of affected area with $R^{2}$ value of 0.683 and $0 \cdot 820$, respectively (Figure 8 ). In addition to soil and water conservation measures, the direct human activities such as reservoir construction and increased water extraction for agricultural irrigation and urban and industrial use in recent decades also contributed to streamflow and sediment load reductions. There were some other soil and water conservation techniques in the world such as cotton geotextiles (Giménez Morera et al., 2010), conservation agriculture (Ndah et al., 2015), and zaï pit and demi-lunes (Wildemeersch et al., 2015). The conservation measures and vegetation restoration also improves soil nutrients and soil quality (Gong et al., 2006; Batjes et al., 2014). However, there were some socio-economic and cultural constraints on adoption of soil and water conservation techniques (Wildemeersch et al., 2015; Ndah et al., 2015).

The obtained linear runoff-sediment yield relationship in this study was not a unique example in the world. Lane et al. (1997) indicated that the event sediment yield and event runoff depth relationship could be fitted with a power function $\left(S S Y_{e}=h_{e}{ }^{1} \cdot 07, R^{2}=0 \cdot 99\right)$ for the $149 \mathrm{~km}^{2}$ Walnut Gulch Experimental watershed in southeastern Arizona, USA. The exponent of 1.07 suggested that this relationship was very likely to be proportional. Gao et al. (2013) reported that the $S S Y_{e}-h_{e}$ relationship could be generally characterized by the proportional model $\left(S S Y_{e}=n h_{e}\right)$ at the plot, unit-source, and watershed scales in semiarid watersheds of southeastern Arizona, USA. The proportional model was a special case of the linear function with a zero intercept in the absence of base flow. As indicated by Zheng (2015), the $x$-intercept of the linear runoff-sediment yield function corresponded to the non-erosive-flow component of streamflow. The base flow is considered as the outflow of the groundwater feeding a river especially during the rainless periods (Aksoy et al., 2009). The base flow is clear and non-erosive, whereas, the surface flow is sediment-laden and erosive (Zheng, 2015). Therefore, the non-erosive-flow component of streamflow can be interpreted to be the base flow. Ferro \& Porto (2012) also indicated that there was a threshold value of discharge ("dominant" or "effective" discharge) to account for certain amount of the total suspended sediment load transported by the river. Furthermore, Zheng (2015) found that the estimated base flows with the $x$-intercept were reasonably comparable with those derived from the Lyne and Hollick filter method in the Loess Plateau.

The average annual and flood season base flow at the five stations were estimated to be 18.92 and $7.01 \mathrm{~mm}$ during the pre-change period, respectively, and the corresponding values during the post-change period were 17.67 and $7.34 \mathrm{~mm}$, respectively. Although the base flow amount did
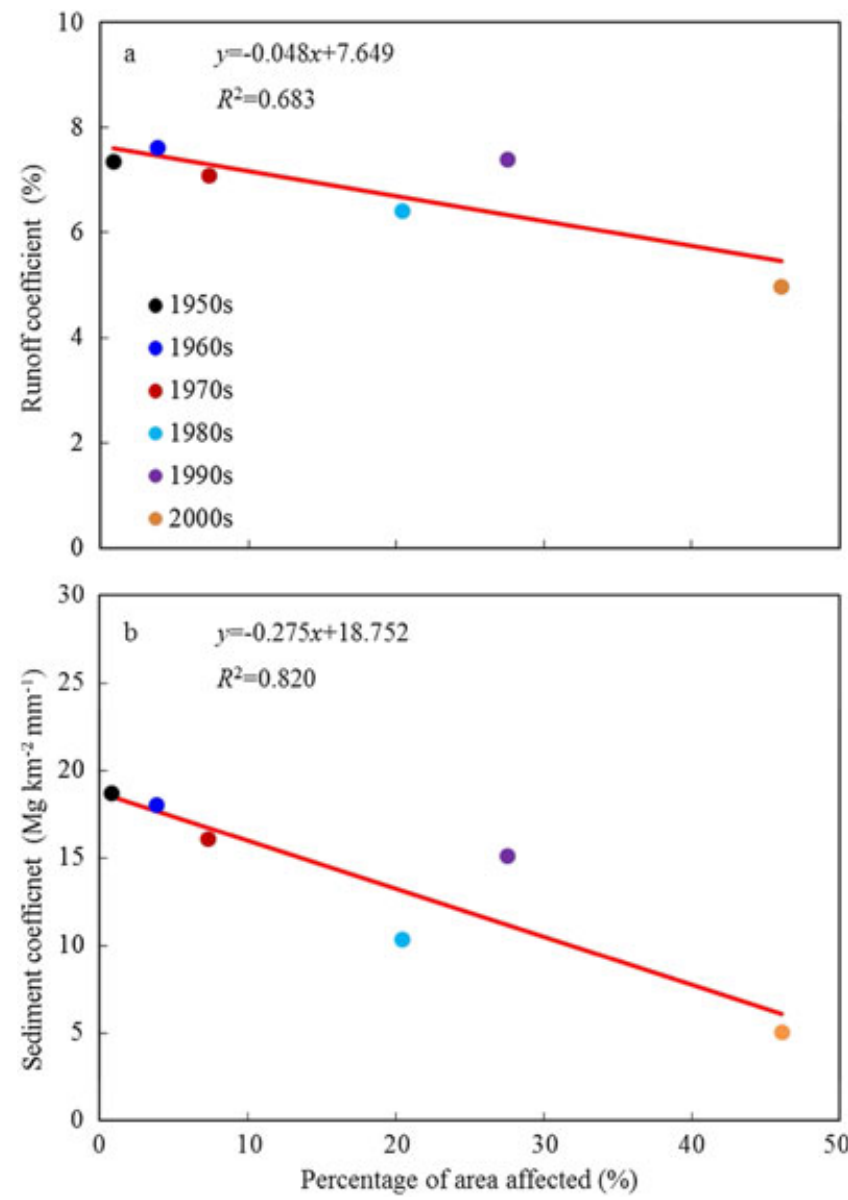

Figure 8. Relationship between the (A) runoff coefficient and (B) sediment coefficient at the Ganguyi station with the percentage of area affected by soil and water conservation measures in different decades. The measures data obtained in 1959, 1969, 1979, 1989, 1999, and 2006 were considered as the records for the 1950s, 1960s, 1970s, 1980s, 1990s, and 2000s, respectively. This figure is available in colour online at wileyonlinelibrary.com/journal/ ldr. 
not show evident change, the proportion of base flow for streamflow greatly increased. The total base flow accounted for $48.63 \%$ and $27.97 \%$ of annual and flood season streamflow during the pre-change period, respectively, whereas the corresponding percentage during the post-change period increased to $69.01 \%$ and $53.03 \%$, respectively. The aforementioned results indicated that the reduction of streamflow was mainly caused by the decrease of surface flow as a result of the trapping efficacy of soil and water conservation measures (Mekonnen et al., 2014).

The increase rate of sediment concentration gradually reduced with the streamflow discharge, and the proposed logarithmic function was adequate to capture this characteristic (Figure 4). Sediment concentration generally increases with flow discharge, however, this increase is not infinite for any physiographic conditions (Asselman, 2000; Zheng et al., 2012). Lana-Renault et al. (2007) indicated that the antecedent humidity and precipitation intensity played an important role in variability of both discharge and suspended sediment concentration during flood events. The upper limit of sediment concentration or the maximum transport capacity is expected to exist under the local control of a given watershed (Alexandrov et al., 2007; Zheng et al., 2008). It appears that the logarithmic function has a universal applicability to describe the aforementioned changes of sediment concentration with streamflow discharge, which permits prediction of sediment discharge by only measuring water discharge in the watersheds of flash hydrological responses.

Despite the implications of this study for watershed streamflow and sediment estimation and management, there are several issues still needing further investigations. First, the distributed hydrological models should be used to simulate the spatial distributions of runoff depth and sediment yield over the watershed, and detect the detailed effects of land cover and climate changes on watershed hydrological processes. Second, the changes of streamflow, sediment load. and flow-sediment relationship on daily and event scales should be conducted if data are available to investigate the dynamic processes governing the temporal changes of sediment transport. This is very useful to prevent flood and sediment-related disasters as a large proportion of runoff and sediment load were commonly generated during a few intense rainstorms in the Loess Plateau. Third, the Yanhe watershed is a typical loess hilly-gully catchment. The obtained results especially the flow-sediment relationships in the Yanhe watershed should be compared with those in other areas with different landform feature such as rocky mountain area and transition zone from sandy area to loess hilly-gully area. Furthermore, the catchments in different climatic zones should also be compared. The aforementioned comparisons are useful to understand the spatial variations of streamflow and sediment over the Loess Plateau.

\section{CONCLUSIONS}

The watershed experienced evident reductions of streamflow and sediment variables, and the reduction became higher from upstream to the midstream and downstream stations. The streamflow at the five stations had the same change point year (1996), and the change point of sediment load in the midstream and downstream (1996) was earlier than that in the upstream station (2002). The runoff-sediment yield relationship on annual, flood season, and monthly scales could be well described by the linear function, and regression lines during the post-change period had lower slope compared with those during the pre-change period of sediment load. Compared with the power function, the logarithmic function was better to describe the annual, flood season, and monthly sediment@@ @oncentration-streamflow discharge relationships which demonstrated consistent behavior during the entire study period. The decrease of sediment concentration in flow had greatest contribution $(65.0 \%)$ to annual sediment load reduction compared with runoff productivity of rainfall $(25.3 \%)$ and precipitation $(9.7 \%)$, whereas the contribution of runoff productivity of rainfall $(35.0 \%)$ increased and sediment concentration in flow $(56.4 \%)$ decreased evidently for flood season sediment load reduction.

\section{ACKNOWLEDGEMENTS}

This research was financially supported by the National Natural Science Foundation of China (41471094 and 41230745), the Young Scientists Fund of RCEES (RCEESQN-20130053 F). We are grateful to the Ecological Environment Database of Loess Plateau, the Yellow River Conservancy Commission, and the National Meteorological Information Center for permitting us access to the hydrological and meteorological data. We thank the editor Artemi Cerdà and three anonymous reviewers for their constructive comments that improved the overall quality of the manuscript.

\section{REFERENCES}

Aksoy H, Kurt I, Eris E. 2009. Filtered smoothed minima base flow separation method. Journal of Hydrology 372: 94-101.

Allen RG, Pereira LS, Raes D, Smith M. 1998. Crop evapotranspiration guidelines for computing crop water requirements. FAO Irrigation and Drainage Paper No. 56: FAO, Rome. http://www.fao.org/docrep/ X0490E/X0490E00.htm

Asselman N. 2000. Fitting and interpretation of sediment rating curves. Journal of Hydrology 234: 228-248.

Bakker MM, Govers G, van Doorn A, Quetier F, Chouvardas D, Rounsevell M. 2008. The response of soil erosion and sediment export to land-use change in four areas of Europe: the importance of landscape pattern. Geomorphology 98: 213-226.

Batjes NH. 2014. Projected changes in soil organic carbon stocks upon adoption of recommended soil and water conservation practices in the upper Tana river catchment, Kenya. Land Degradation and Development 25: 278-287. DOI:10.1002/ldr.2141.

Begueria S, Lopez-Moreno JI, Lorente A, Seeger M, García-Ruiz JM. 2003. Assessing the effects of climate oscillations and land-use changes on streamflow in the Central Spanish Pyrenees. Ambio 32: 283-286.

Berendse F, van Ruijven J, Jongejans E, Keesstra S. 2015. Loss of plant species diversity reduces soil erosion resistance. Ecosystems 18: 881-888. DOI:10.1007/s10021-015-9869-6.

Bisantino T, Bingner R, Chouaib W, Gentile F, Trisorio LG. 2015. Estimation of runoff, peak discharge and sediment load at the event scale in a 
medium-size Mediterranean watershed using the Annagnps model. Land Degradation and Development 26: 340-355. DOI:10.1002/ldr.2213.

Boix-Fayos C, Barbera GG, Lopez-Bermudez F, Castillo VM. 2007. Effects of check dams, reforestation and land-use changes on river channel morphology: case study of the Rogativa catchment (Murcia, Spain). Geomorphology 91: 103-123.

Borrelli P, Märker M, Schütt B. 2015. Modelling post-tree-harvesting soil erosion and sediment deposition potential in the Turano River basin (Italian Central Apennine). Land Degradation \& Development 26: 356-366. DOI:10.1002/ldr.2214.

Borselli L, Cassi P, Torri D. 2008. Prolegomena to sediment and flow connectivity in the landscape: a GIS and field numerical assessment. Catena 75: 268-277.

Brevik EC, Cerdà A, Mataix-Solera J, Pereg L, Quinton JN, Six J, Van Oost K. 2015. The interdisciplinary nature of SOIL. SOIL 1: 117-129. DOI:10.5194/soil-1-117-2015.

Buendia C, Vericat D, Batalla RJ, Gibbins CN. 2015. Temporal dynamics of sediment transport and transient in-channel storage in a highly erodible catchment. Land Degradation \& Development . DOI:10.1002/ldr.2348.

Cerdà A. 1998. The influence of geomorphological position and vegetation cover on the erosional and hydrological processes on a Mediterranean hillslope. Hydrological Processes 12: 661-671.

Cerdà A, Doerr S. 2005. The influence of vegetation recovery on soil hydrology and erodibility following fire: an eleven-year research. International Journal of Wildland Fire 14: 423-437. DOI:10.1071/WF05044.

Cohen S, Kettner AJ, Syvitski JPM. 2014. Global suspended sediment and water discharge dynamics between 1960 and 2010: continental trends and intra-basin sensitivity. Global and Planetary Change 115: 44-58.

Feng XM, Sun G, Fu BJ, Su CH, Liu Y, Lamparski H. 2012. Regional effects of vegetation restoration on water yield across the Loess Plateau, China. Hydrology and Earth System Sciences 16: 2617-2628.

Ferro V, Porto P. 2012. Identifying a dominant discharge for natural rivers in southern Italy. Geomorphology 139-140: 313-321.

Fu BJ, Gulinck H. 1994. Land evaluation in area of severe erosion: the Loess Plateau of China. Land Degradation \& Development 5: 33-40. DOI:10.1002/ldr.3400050105.

Fu BJ, Zhao WW, Chen LD, Zhang QJ, Lü YH, Gulinck H, Poesen J. 2005. Assessment of soil erosion at large watershed scale using RUSLE and GIS: a case study in the Loess Plateau of China. Land Degradation \& Development 16: 73-85. DOI:10.1002/ldr.646.

Gabarrón-Galeote MA, Martínez-Murillo JF, Quesada MA, Ruiz-Sinoga JD. 2013. Seasonal changes in the soil hydrological and erosive response depending on aspect, vegetation type and soil water repellency in different Mediterranean micro environments. Solid Earth 4: 497-509. DOI: $10.5194 /$ se-4-497-2013

Gao P, Nearing MA, Commons M. 2013. Suspended sediment transport at the instantaneous and event time scales in semiarid watersheds of southeastern Arizona. USA. Water Resources Research 49. DOI:10.1002/ wrcr.20549.

Gao P, Jiang GT, Wei YP, Mu XM, Wang F, Zhao GJ, Sun WY. 2015. Streamflow regimes of the Yanhe River under climate and land use change, Loess Plateau, China. Hydrological Processes 29: 2402-2413. DOI:10.1002/hyp.10309.

Gao ZL, Fu YL, Li YH, Liu JX, Chen N, Zhang XP. 2012. Trends of streamflow, sediment load and their dynamic relation for the catchments in the middle reaches of the Yellow River over the past five decades. Hydrology and Earth System Sciences 16: 3219-3231.

Giménez-Morera A, Ruiz Sinoga JD, Cerdà A. 2010. The impact of cotton geotextiles on soil and water losses in Mediterranean rainfed agricultural land. Land Degradation and Development 21: 210-217. DOI:10.1002/ ldr.971.

Gong J, Chen L, Fu B, Huang Y, Huang Z, Peng H. 2006. Effect of land use on soil nutrients in the loess hilly area of the Loess Plateau, China. Land Degradation \& Development 17: 453-465. DOI:10.1002/ldr.701.

Hirsch RM, Slack JR, Smith RA. 1982. Techniques of trend analysis for monthly water quality data. Water Resources Research 18: 107-121.

Huang MB, Zhang L. 2004. Hydrological responses to conservation practices in a catchment of the Loess Plateau, China. Hydrological Processes 18: $1885-1898$.

Huo ZL, Feng SY, Kang SZ, Li WC, Chen SJ. 2008. Effects of climate changes and water-related human activities on annual stream flows of the Shiyang river basin in arid north-west China. Hydrological Processes 22: $3155-3167$.
Keesstra SD. 2007. Impact of natural reforestation on floodplain sedimentation in the Dragonja basin, SW Slovenia. Earth Surface Processes and Landforms 32: 49-65. DOI:10.1002/esp.1360.

Keesstra SD, Bruijnzeel LA, van Huissteden J. 2009. Meso-scale catchment sediment budgets: combining field surveys and modeling in the Dragonja catchment, southwest Slovenia. Earth Surface Processes and Landforms 34: 1547-1561.

Keesstra SD, Geissen V, Mosse K, Piiranen S, Scudiero E, Leistra M, van Schaik L. 2012. Soil as a filter for groundwater quality. Current Opinions in Environmental Sustainability 4: 507-516. DOI:10.1016/j. cosust.2012.10.007.

Keesstra SD, Kondrlova E, Czajka A, Seeger M, Maroulis J. 2012. Assessing riparian zone impacts on water and sediment movement: a new approach. Netherlands Journal of Geosciences 91: 245-255.

Keesstra SD, Temme AJAM, Schoorl JM, Visser SM. 2014. Evaluating the hydrological component of the new catchment-scale sediment delivery model LAPSUS-D. Geomorphology 212: 97-107.

Kendall MG. 1975. Rank correlation measures. London, UK: Charles Griffin. Kröpfl AI, Cecchi GA, Villasuso NM, Distel RA. 2013. Degradation and recovery processes in semi-arid patchy rangelands of northern Patagonia, Argentina. Land Degradation \& Development 24: 393-399. DOI:10.1002/ldr.1145

Lana-Renault N, Regues D, Marti-Bono C, Beguería S, Latron J, Nadal E, Serrano P, García-Ruiz JM. 2007. Temporal variability in the relationships between precipitation, discharge and suspended sediment concentration in a small Mediterranean mountain catchment. Nordic Hydrology 38: 139-150.

Lane LJ, Hernandez M, Nichols M. 1997. Processes controlling sediment yield from watersheds as functions of spatial scale. Environmental and Modeling Software 12: 355-369.

Liang W, Bai D, Wang FY, Fu BJ, Yan JP, Wang S, Yang YT, Long D, Feng MQ. 2015. Quantifying the impacts of climate change and ecological restoration on streamflow changes based on a Budyko hydrological model in China's Loess Plateau. Water Resources Research DOI:10.1002/2014WR016589.

Liu XY, Yang ST, Dang SZ, Luo Y, Li XY, Zhou X. 2014. Response of sediment yield to vegetation restoration at a large spatial scale in the Loess Plateau. Science China-Technological Sciences 57: 1482-1489.

Liu Z, Yao Z, Huang H, Wu S, Liu G. 2014. Land use and climate changes and their impacts on runoff in the Yarlung Zangbo river basin, China. Land Degradation and Development 25: 203-215. DOI:10.1002/ldr.1159.

Mann HB. 1945. Nonparametric tests against trend. Econometrica 13: 245-259.

Marchamalo M, Hooke JM, Sandercock PJ. 2015. Flow and sediment connectivity in semi-arid landscapes in SE Spain: patterns and controls. Land Degradation \& Development . DOI:10.1002/ldr.2352.

Miao CY, Ni JR, Borthwick AGL. 2010. Recent changes of water discharge and sediment load in the Yellow River basin, China. Progress in Physical Geography 34: 541-561.

Miao CY, Yang L, Chen XH, Gao Y. 2012. The vegetation cover dynamics (1982-2006) in different erosion regions of the Yellow River Basin, China. Land Degradation \& Development 23: 62-71. DOI:10.1002/ldr.1050.

Mekonnen M, Keesstra SD, Stroosnijder L, Baartman JEM, Maroulis J. 2014. Soil conservation through sediment trapping: a review. Land Degradation \& Development. DOI:10.1002/ldr.2308.

Mekonnen M, Keesstra SD, Baartman JE, Ritsema CJ, Melesse AM. 2015. Evaluating sediment storage dams: structural off-site sediment trapping measures in northwest Ethiopia. Cuadernos de Investigación Geográfica 41: 7-22. DOI: 10.18172/cig.2643.

McVicar TR, Li LT, Van Niel TG, Zhang L, Li R, Yang QK, Zhang XP, Mu XM, Wen ZM, Liu WZ, Zhao YA, Liu ZH, Gao P. 2007. Developing a decision support tool for China's re-vegetation program: Simulating regional impacts of afforestation on average annual streamflow in the Loess Plateau. Forest and Ecology Management 251: 65-81.

Milly PCD, Dunne KA, Vecchia AV. 2005. Global pattern of trends in streamflow and water availability in a changing climate. Nature 438: 347-350. Muñoz-Rojas M, Jordán A, Zavala LM, De la Rosa D, Abd-Elmabod SK, Anaya-Romero M. 2012. Organic carbon stocks in Mediterranean soil types under different land uses (Southern Spain). Solid Earth 3: 375-386. DOI:10.5194/se-3-375-2012.

Mu XM, Zhang L, McVicar TR, Chille B, Gao P. 2007. Analysis of the impact of conservation measures on stream flow regime in catchments of the Loess Plateau. China Hydrological Processes 21: 2124-2134. 
Ndah HT, Schuler J, Uthes S, Zander P, Triomphe B, Mkomwa S, Corbeels M. 2015. Adoption potential for conservation agriculture in Africa: a newly developed assessment approach (QAToCA) applied in Kenya and Tanzania. Land Degradation and Development 26: 133-141. DOI: $10.1002 /$ ldr.2191.

Parras-Alcántara L, Martín-Carrillo M, Lozano-García B. 2013. Impacts of land use change in soil carbon and nitrogen in a Mediterranean agricultural area (Southern Spain). Solid Earth 4: 167-177. DOI:10.5194/se-4-167-2013.

Pettitt AN. 1979. A non-parametric approach to the change-point problem. Applied Statistics 28: 126-135.

Qadir M, Noble AD, Chartres C. 2013. Adapting to climate change by improving water productivity of soil in dry areas. Land Degradation \& Development 24: 12-21. DOI:10.1002/ldr.1091.

Quiñonero-Rubio JM, Nadeu E, Boix-Fayos C, de Vente J. 2014. Evaluation of the effectiveness of forest restoration and check-dams to reduce catchment sediment yield. Land Degradation \& Development . DOI:10.1002/ldr.2331.

Raupach MR, Marland G, Ciais P, Le Quéré C, Canadell JG, Klepper G, Field CB. 2007. Global and regional drivers of accelerating $\mathrm{CO}_{2}$ emissions. Proceedings of the National Academy of Sciences of the United States of America 104: 10288-10293.

Rustomji P, Zhang XP, Hairsine PB, Zhang L, Zhao J. 2008. River sediment load and concentration responses to changes in hydrology and catchment management in the Loess Plateau of China. Water Resources Research 44: W00A04. DOI:10.1029/2007WR006656.

Sanjuán Y, Gómez-Villar A, Nadal-Romero E, Álvarez-Martínez J, Arnáez J, Serrano-Muela MP, Rubiales JM, González-Sampériz P, García-Ruiz JM. 2014. Linking land cover changes in the sub-alpine and montane belts to changes in a torrential river. Land Degradation and Development . DOI: $10.1002 / \mathrm{ldr} .2294$.

Sen PK. 1968. Estimates of the regression coefficient based on Kendall's tau. Journal of the American Statistical Association 63: 1379-1389.

Serrano-Muela MP, Nadal-Romero E, Lana-Renault N, González-Hidalgo JC, López-Moreno JI, Beguería S, Sanjuan Y, García-Ruiz JM. 2015. An exceptional rainfall event in the central western Pyrenees: spatial patterns in discharge and impact. Land Degradation and Development 26: 249-262. DOI:10.1002/ldr.2221.

Shi ZH, Ai L, Li X, Huang XD, Wu GL, Liao W. 2013. Partial least-squares regression for linking land-cover patterns to soil erosion and sediment yield in watersheds. Journal of Hydrology 498: 165-176.

Walling DE, Fang D. 2003. Recent trends in the suspended sediment loads of the world rivers. Global and Planetary Change 39: 111-126.

Wang D, Fu BJ, Zhao WW, Hu HF, Wang YF. 2008. Multifractal characteristics of soil particle size distribution under different land-use types on the Loess Plateau, China. Catena 72: 29-36.
Van Nieuwenhuyse BHJ, Antoine M, Wyseure G, Govers G. 2011. Pattern-process relationships in surface hydrology: hydrological connectivity expressed in landscape metrics. Hydrological Processes 25: 3760-3773.

Wildemeersch JCJ, Timmerman E, Mazijn B, Sabiou M, Ibro G, Garba M, Cornelis W. 2015. Assessing the constraints to adopt water and soil conservation techniques in Tillaberi, Niger. Land Degradation and Development 26: 491-501. DOI:10.1002/ldr.2252.

Xu XL, Scanlon BR, Schilling K, Sun A. 2013. Relative importance of climate and land surface changes on hydrologic changes in the US Midwest since the 1930s: implications for biofuel production. Journal of Hydrology 497: 110-120.

Xu YD, Fu BJ, He CS. 2013. Assessing the hydrological effect of check dams in the Loess Plateau, China, by model simulations. Hydrology and Earth System Sciences 17: 2185-2193.

Yue S, Wang CY. 2002. Applicability of prewhitening to eliminate the influence of serial correlation on the Mann-Kendall test. Water Resources Research 38: 1068. DOI:10.1029/2001WR000861.

Zhang F, Tiyip T, Feng ZD, Kung H-T, Johnson VC, Ding JL, Tashpolat N, Sawut M, Gui DW. 2015. Spatio-temporal patterns of land use/cover changes over the past 20 years in the middle reaches of the Tarim River, Xinjiang, China. Land Degradation \& Development 26: 284-299. DOI:10.1002/ldr.2206.

Zhang XP, Zhang L, Zhao J, Rustomji P, Hairsine P. 2008. Responses of streamflow to changes in climate and land use/cover in the Loess Plateau, China. Water Resources Research 44: W00A07. DOI:10.1029/2007W R006711.

Zhao GJ, Tian P, Mu XM, Jiao JY, Wang F, Gao P. 2014. Quantifying the impact of climate variability and human activities on streamflow in the middle reaches of the Yellow River basin, China. Journal of Hydrology 519: 387-398.

Zhao G, Mu X, Wen Z, Wang F, Gao P. 2013. Soil erosion, conservation, and eco-environment changes in the Loess Plateau of China. Land Degradation \& Development 24: 499-510. DOI:10.1002/ldr.2373.

Zhao WW, Fu BJ, Chen LD. 2012. A comparison between soil loss evaluation index and C-factor of RUSLE: a case study in the Loess Plateau of China. Hydrology and Earth System Sciences 16: 2739-2748.

Zheng MG, Cai QG, Cheng QJ. 2008. Modelling the runoff-sediment yield relationship using a proportional function in hilly areas of the Loess Plateau, North China. Geomorphology 93: 288-301.

Zheng MG, Yang JS, Qi DL, Sun LY, Cai QG. 2012. Flow-sediment relationship as functions of spatial and temporal scales in hilly areas of the Chinese Loess Plateau. Catena 98: 29-40.

Zheng MG. 2015. Estimation of base flow using flow-sediment relationships in the Chinese Loess Plateau. Catena 125: 129-134. 